\title{
A DOCUMENT OF IBADI FIQH GOVERNING THE ARCHITECTURE OF MOSQUES
}

| Received June 2nd 2016 | Accepted June 15th 2016 | Available online December 20th 2016 |

| DOI http://dx. doi. org/10.18860/jia.v4i2.3487 |

\section{Naima Benkari}

Department of Civil and Architecture

Sultan Qaboos University

Oman

n.benkari4@gmail.com

\begin{abstract}
In spite of a long-standing interest in the lbadi community and its historical social, religious and architectural legacy, its Ibadi scholarly literature remains largely unknown. In spite of a long-standing interest in the lbadi community and its historical, social, religious and architectural legacy, its Ibadi scholarly literature remains largely unknown. The present research continues in the footsteps of the pioneering works of Joseph Schacht and Pierre Cuperly on Ibadism [1], [2]. It aims to cast light on the lbadi literature that represents an authentic source of information for the study of Ibadism past and present. This article analyzes an lbadi manuscript from the twelfth century written by the scholar Abul'Abbas Ahmad. This document has been the primary reference for the most important sources of Ibadi legislation still in use by the community in its three main centers: M'zab, Djerba and Oman. The study of this document, along with other Ibadi scholarly literature on this topic, shows that this jurisprudence has regulated in detail the design construction and management of mosques, and that this level of careful attention was due to the importance of the mosque for the instruction and organization of the community.
\end{abstract}

KEYWORDS:

Ibadism; jurisprudence; Ibadi figh; 'urf; mosque architecture; M'zab; Djerba; Oman; mihrab; minaret; prayer niche

\section{INTRODUCTION}

A variety of interesting works have been written about the architecture produced by lbadi groups, especially in the region of M'zab. Most of these studies were particularly interested in urban organization and development [3], vernacular housing [4],[5]. The Ibadi mosque was also addressed but the approach to this topic was mainly descriptive or historical. Research that attempted to analyze the built environment produced by Ibadi groups via the study of their legislative sources is quite rare. This is probably due to the fact that the introverted character of this community made it difficult for researchers to access the corpus of Ibadi scholarly literature in general, and specifically the legislative sources regulating the built environment.

\section{IBADI SOURCES REGULATING PRODUCTION AND} MANAGEMENT OF THE BUILT ENVIRONMENT

To express any legal opinion, the Ibadi scholars refer to the texts from the Quran, then the Hadith andthe Sunnah. The third source is represented by the collection of precedent opinions expressed by previous scholars, whether accepted by consensus among scholars (ijmâ') or approved by only a few among them as the result of ijtihâd. The fourth reference or source of legislation is the tradition and social practice, "urf [6]. While the two first sources are the same for any school of thought in Islam, ijtihâd and 'urf vary from one school of thought to another.
In the Ibadi School and with regard to the production and management of the built environment, there are two major references which have retained their influence for centuries. The first text is Kitâbalqismahwa usûl al-aradîn, by the scholar Abûl-'Abbâs Ahmad, from the beginning of the twelfth century [7]. This book is essentially the compilation of the legal opinions of Ibadi scholars from the island of Djerba (now part of Tunisia). It addresses settlement development and management in North Africa and the distribution of land, and relates some precedents of property conflicts between neighbors and how they could be solved [8]. The French Orientalist Pierre Cuperly was the first researcher to reveal the content of Kitâb al-qismah in his article about the social life of the Ibadis in the region of M'zab in southern Algeria and the organization of their cities [9].

The second Ibadi reference dates back to the beginning of the twentieth century. Titled Mukhtașar al-'imârah, this book was written by the Algerian Ibadi scholar Mohammad Ben Youssef Atfiyech. The same themes addressed in Kitâb al-qismah would be treated in Mukhtașar al-'imârah, with the addition of details about some specific topics in the field of construction such as the positioning of doors and waterspouts, giving consideration to public spaces and their users. While the Sunni school of thought has produced some major references about the jurisprudence related to the construction and management of mosques [10], it was not known outside the Ibadi community that the Ibadi scholars had produced similar references. The 
present research revealed that a comprehensive set of regulations governing the construction and management of religious buildings in the Ibadi school of thought is indeed contained in its figh (Islamic jurisprudence) references.

After consulting many lbadi sources and according to the accounts collected from the Ibadi scholars interviewed in this study, it has been established that Al-Muṣannaf and Al-nîl wa sharhkitâb al-nîl [11], [8], represent the two major references used by Ibadi scholars to address and regulate the different aspects of the community's everyday life. Al-Musannaf is the reference for Ibadis in Oman and Zanzibar, and Al-nîl wa sharhkitâb al-nîl is the reference in the M'zab valley and the island of Djerba. As it is the case for most of the Ibadi figh sources, the subject matter of these books, along with a number of other questions related to the community life and recommended practices, is organized into several volume streating mu'âmalât. Most of the texts related to the architecture of mosques, the process of their construction and the management of their property, are arranged under the chapter titled "The mosque's rights" (huqûq al-masjid).

\section{AL-MUSANNAF BY ABU BAKR AHMED}

Abu Bakr Aḥmad bin 'Abdullâh bin MûsâalKindîal-Șamadîal-Nizwî, was an Ibadi theologian from the Omani city of Nizwa. He wrote Al-Musannaf around $557 \mathrm{AH} / 1162 \mathrm{CE}$. This book is the main reference of later Ibadi theologians, especially in Oman. This makes it an important and authentic source to explore for this current research. In two of the volumes dedicated to mu'âmalât, Al-Mușannaf addresses various questions regarding land use and management and how this is regulated by Ibadi laws. Issues related to the architecture of the mosques, their awqâf [12] (endowments) and management are presented in volumes five, twelve, and especially nineteen. Analysis of these volumes yields Ibadi scholarly verdicts regarding the architecture of mosques. In the following sections, we present the most dominant of these opinions.

\section{MAIN THEMES RELATED TO RELIGIOUS ARCHITECTURE IN} IBADI JURISPRUDENCE AS PRESENTED IN AL-MUSANNAF

1. Encouraging the construction of mosques as a pious act

In the religion of Islam, any place on earth could be a prayer space, as stated in several hadiths of the Prophet Muhammad (PBUH), such as:

"And the earth has been consecrated (to me) as a masjid (place of prostration) and its dust as purification. "(a sound hadith related by Ibn Majah).

However, the ideal space to perform the salât (formal prayer), in the opinion of all Muslim scholars, is indeed what has been dedicated and prepared for this function: the masjid (lit. place of prostration), or the mosque. To illustrate this idea, the author of AlMusannaf, like other Ibadi scholars, refers to the following Quranic verses:
"In houses (mosques), which Allah has ordered to be raised (to be cleaned, and to be honoured), in them His Name is glorified in the mornings and in the afternoons or the evenings " (Quran, Sûrat al-Nûr 24:36) And,

"Who is more unjust than him who forbids the remembrance of God's name in places of worship, and contributes to their ruin? These ought not to enter them except in fear. For them is disgrace in this world, and for them is a terrible punishment in the Hereafter "(Quran, Sûrat al-Baqarah2:114).

All the scholars insist on the importance of the mosque in any settlement and how sacred it is, and therefore, how generous must be the divine reward expected for those who build mosques by their efforts or through their funds [13].

"...And based on the saying of 'Amr bin Shu'aib, who reported it from his father: He who builds a masjid without arrogance, even if this Masjid is as small as a qatât's nest, Allah will build for him a house in paradise" [14].

Ibadi scholars believe that it is not recommended to accomplish such a pious action as building a mosque if one's intention is to show offto people [13]. This position, shared by all the Sunni schools of thought includes also the very architecture of the building [10]. Indeed, the scholars state that it is not praiseworthy to erect sanctuaries that are grandiose in their dimensions, forms, or decoration. The reason is that this kind of building diverts the attention of the worshiper away from the sacred action of prayer, and from the adoration of Allah the supreme Creator to the admiration of the artificial beauty of the space.

2. Funding the construction, maintenance, and restoration of the mosque

By reason of its sacred status in Islam, the construction, furnishing, and maintenance of the mosque must be funded from halal (permissible) sources [10]. The lbadi laws mention three possible sources of funds for the mosque, whether it is a jâma or a masjid fard. The first source of funding is the waqf designated for the construction and maintenance of the mosque [13]. The second is the community's treasury, known asbaït al-mâl [13]. The third source is the direct and voluntary participation of the community's members, even if they are not Muslims [15], [13], as long the money they offer is fromNpermissible sources. This third source of funding is only for the jâma'. The dominant opinion among the scholars is that the community should not be asked to fund the construction of the masjid fard; instead, the funds should be taken from the bait al-mâl [13] However, a certain number of scholars, among them Abu Bakr Ahmad, consider it necessary to encourage the community to participate in the construction of the mosque [13]. To support their position these scholars refer to this hadith:

"A' 'ishah narrated:'The Prophet ordered his community to build mosques in the neighborhoods and to clean them and perfume them with incense" [13].

All the essential components of the mosque, such as the walls, roofs, pillars, floors, stairs, and even the waterspouts (mizâb), must be funded from the 
money designated for its construction [13]. The mușallah (open area for prayer), however, must not be built with the same money as the mosque. Some scholars consider that what has been designated for serving the mosque must not be used for the musallah. Similarly, money designated for the latter cannot be used in the service of the mosque [8]. Funds dedicated to the construction of a mosque can also be used for its reconstruction if it collapses partially or entirely. If the assets belonging to the mosque are not sufficient to fund its reconstruction, then the persons or institutions legally responsible for the mosque must complete its reconstruction [14].

\section{Tarîq al-masjid: the route to the mosque}

All the Ibadi scholars consider it necessary to provide and build streets and walkways leading to the mosque [11], [13]. If the funds designated for the construction of the sanctuary or its awqâf, are insufficient, some must be used to acquire the right of transit and to build a path or street linking the mosque to the nearest main street or road [15]. If the mosque does not possess enough money or assets, then this path must be funded by the treasury (bait al-mâl) [15]. If someone possesses land close to the mosque and wants to build on it, s/he must leave a passage to the mosque through his/her land. S/He could sell it to the sanctuary or, even better, offer it to the mosque as an endowment [13]. The path of the mosque (whether it is ajâma'or a masjidfard) must have a buffer zone (harîm) of two or three cubits (dhirâ', around one meter and a half to two meters) from each side [13], [15].

\section{Consecration of the mosque and the status of its land}

The Ibadis, like their counterparts in the other schools of thought in Islam, consider that for a building to acquire the sacredness of a mosque and be suitable to host prayers this structure must have been built with an expressed intention to make it a mosque [15]. It is this articulated intention to consecrate it for $\mathrm{t}$ he worship of Allah that in lbadi juris prudence distinguishes the sacred status of a mosque from other structures [16]. The scholars specify that the intention must be expressed (out loud or in one's mind) while the first foundation stone or așâs of the mosque is being laid [15]. More recent theologians in the Ibadi school are of the view that in addition to the articulation of intention a general consensus among all the involved residents must be clearly expressed and the approval of the leading religious people ( $a \mathrm{hl}$ al$\left.d a^{\prime} w a h\right)$ in the city are mandatory for a construction to acquire the status of a mosque. All the Ibadi scholars adhere to the principle that a structure built with the intention to make it a mosque will keep this status forever, even after it falls to ruins. Even if a collapsed mosque is completely effaced, the parcel on which it was built keeps the status of sacred space forever [13],[15]. This legal opinion could help explain the great number of mosques that are still more or less preserved although no longer used, found in Oman, Djerba Island and in the M'zab.

\section{The issue of shared partitions with a mosque}

The question of shared partitions with mosques has been addressed by Ibadi scholars to regulate the interactions between the mosque's users and the building's neighbors. The texts analyzed in this research deal with two major cases of shared partitions: the case of a mosque attached to a cave [8], and the situation of a mosque built on the roof of a house or over a shop. Ibadi jurisprudence allows such situations under the condition that the place, once occupied by the mosque, should never be allocated to another function, even if the mosque collapses or disappears. If the construction of the mosque causes damage to the neighboring buildings, the repairs should paid for out of the budget dedicated to the construction of the mosque [13].

\section{The architecture of the mosque and the spaces it contains}

The documents of Ibadi figh consulted for this research do not speak about all the spaces that might compose a sanctuary dedicated to this ritual. Similarly, the components cited by these references are addressed with varying degrees of interest. The following section presents the most important components addressed in the Ibadi scholarly references, particularly in Al-Mușannaf.

\section{a- The prayer hall: al-masjid or bait al-ṣalât}

Ibadi jurisprudence does not define any specific form for the mosque, while other Sunni schools recommend a square shape [10]. This attitude towards the sanctuary form seems to be reflected in the wide array of forms observed in the Ibadi religious architecture. Whereas the mosques in Djerba and especially in Oman adopt regular forms, generally square or rectangular, the sanctuaries of the M'zab present more irregular and even organic shapes of mosques (Figure 1). The majority of scholars affirm the necessity to build the prayer hall large enough to host the number of worshipers who might use it during the congregational prayers [13],[15]. Some scholars, however, gave no opinions about the recommended dimensions of the prayer hall, and others did not express any prohibition against small prayer halls. Regarding the height of the sanctuary in the settlement, certain scholars prohibited the construction of houses higher or in elevated terrains that make them appear higher than the prayer hall (bait al-șalât), except if those structures had been built before the construction of the mosque. This aspect is reflected essentially in the great mosques in the M'zab and most of the lbadi sanctuaries in Oman.

\section{b- The roof of the mosque, its height and shape}

The choice of construction technique and the form of the roof of the mosque has been left to the builders or whoever is responsible for the construction of the sanctuary. Thus, it is local practice, 'urf, that will be the reference in this aspect. However, the debate among the Ibadi scholars was about the height recommended for the roof of the mosque. Certain theologians argue that it is not recommended to elevate the roof of the mosque more than is necessary. They base their opinion on the fact that the Prophet Mohamad (PBUH) had expressed this same view [13], 
[15], even if there is no factual information about the height of the Prophet's mosque [17]. Other Ibadi scholars prohibit the construction of mosques with a very low roof, which following their argument, risks to diminish the status of the sanctuary. A third group allows the elevation of the mosque's roof above the regular or common height of buildings in the settlement [8]. These debates have generated some diversity in the choices adopted by the builders for mosque roofs. Their forms and heights vary from one region to another, and even in the same region fromone period to the next [7].

\section{c- The courtyard: sahn, sarhah/sarh or rahbah}

The references of Islamic figh give different names to the mosque's courtyard, which is generally used as an open-air prayer space: $s a h n$, sarhah/șarh or rahbah. As a result, in the intense exchanges between the oriental Ibadis and their coreligionists in the Maghreb, and in the transmission of expertise between them, all these terms are widely used through out the regions that are home to Ibadism. The status given to the courtyard by Ibadi jurisprudence is unanimous. The sahn of a mosque is part and parcel of it, and is considered as sacred as the sanctuary [13]. However, the sources examined do not address the form, dimensions, or even the situation of the courtyard in the mosque. The only indication in this regard was expressed by Abu Bakr Ahmad, who stated that it is acceptable to elevate the courtyard above the street leading to it [13]. It must be noted here that different and irregular shapes are observed in the courtyards of Ibadi mosques, even if the rectangular shape is the most common (Figure 1).
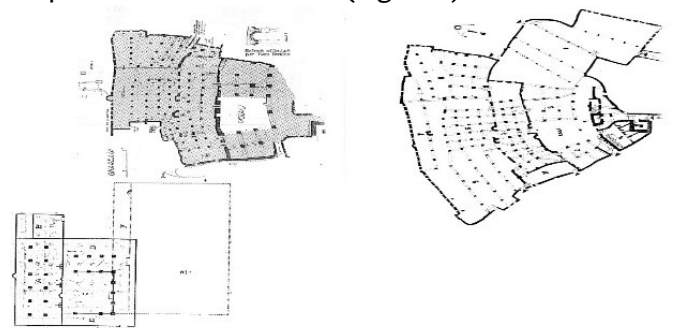

a. Spatial evolution of the great mosque of Ghardaïa (N. Benkari)

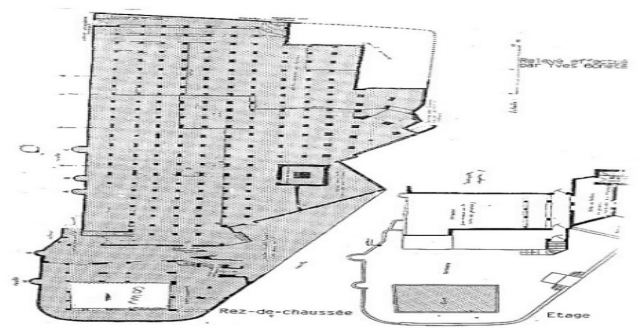

b. The great mosque of Beni Izguen (Bonète1961)

Figure 1: Two mosques in the M'zab

\section{The status of the minaret}

The sawma'ah (lit. cell, hermitage) and the manârah (minaret; lit. place emitting light) are two components that may exist together or separately in the Ibadi mosque. They are different in their status, function and even in the etymology of their names. The Ibadi scholars are very specific regarding the status of each element. Ath-Thamînî establishes the difference between sawma'ah (the space from where the call to prayer is given) and the manârah. This latter he considers as an annex to the mosque, serving as a watch tower or surveillance vantage point from where the guards could also communicate with other mosques far away for defensive purposes [15]. Abu Bakr Ahmad, on the other hand, does not consider the manârah to be part of the mosque [13].

There is no indication in the figh texts about the form, height or construction materials for the minaret. Ath-Thamînî (1967) specifies that if a șawma'a his to be built, it must be installed in a way to face the qiblah wall or on one of its sides. The reason behind this is to avoid the muezzin having to turn his back to the qiblah while calling to the prayer, as the validity of the call to prayer depends on the position of the muezzin, among other conditions [16].

For the Ibadi scholars, the minaret, whether it is a sawma'ah or a manârah, is not an essential component of the mosque. They are very keen to follow the traditional construction methods and processes used by the Muslims of the time of the Prophet (PBUH) or of his companions. It is probable that the relative unimportance that the Ibadi scholars assign to the manârah or șawma'a his related to the fact that this element did not exist in the Prophet's mosque. This could explain the absence of this element in all the traditional Ibadi mosques in M'zab and in a large number of those of Djerba and Oman.

\section{The status of the milhrâb}

The mihrâb is the niche that marks the center of the qiblah wall in every mosque. This element helps to orient worshipers towards the Kaaba for their prayers [18]. During the Prophet's life time, the mihrâb in its concave shape that is known today did not exist. Therefore, Muslim scholars have different views about the form of this element. The consulted references in the corpus oflbadi jurisprudence do not address the form, the dimensions or the construction materials of the milhrâb. Abu Bakr Ahmad simply evokes the necessity to orient the mosque towards the Kaaba [13]. However, the issue of adornment of this element has been thoroughly debated. A synthesis of this debate is presented in the section of this paper dedicated to the question of ornamentation.

\section{Architectural details and construction materials}

Choosing the materials for the construction of the mosque was left to the common practice in any particular community ('urf) [11], with the condition that these materials must be halal, pure, and belonging to the mosque or whoever has donated them to this project [13]. Ibadi theologians agree that the sanctuary must be simply built with affordable local materials. Here again, the reference for such a legal position must have been the construction process and methods of the Prophet's mosque in Medina.

"The mosque of the Prophet (PBUH) was built with stones and palm trees. Its pillars were made of tree trunks planted in the ground. Its roof was out of interwoven palm leaves" [15]. 


\section{Furnishings and lighting}

According tolbadi jurisprudence, carpets and other furnishings usually needed in the mosque or for the prayer (such as bookshelves and Quran stands) are not the property of the mosque: they belong to the worshipers. Therefore, they are not included in the budget dedicated to the mosque. They are usually included in another budget specifically assigned for this purpose [13].

All the lbadi religious sources consulted recommend keeping the mosque always illuminated, clean, and with a pleasant fragrance, so that worshipers would feel comfortable being there even at night [15]. This recommendation is also for the mosques which might not be used at night. Lamps must be placed so that the qiblah wall or direction is easily visible. Lamps must also be located at suitable spots to allow the worshiper to perform the prayer and/or read the Quran, and to move with ease in the prayer hall without being forced to take the lamp along to light the way. Indeed, once illuminated, the lamps must not be moved; this is to avoid accidents and possibly fire in the mosque and also to avoid disturbing other worshipers who also need the light for their activities [15].

\section{Decoration and ornamentation of the mosque}

All Ibadi scholars insist on the principle of prohibiting excessive decoration or adornment in any type of construction in general, and especially in religious buildings [15]. They consider that cleaning and repairing the mosques are their ultimate decoration [13], and they encourage worshipers to respect these buildings by continuously evoking Allah's name and supplicating while they are in the mosque [13], [15]. The interdiction of ornamenting the mosques concerns both their exterior walls and their interior spaces. Ibadi rulings prohibit any ornamentation on the façade of the mosque, even if this decoration only consists of crenellations [13].

With regard to the interior spaces, the scholars have specified three aspects: wall painting or carving and decoration of the floors with colorful carpets; decoration of the space by hanging up pictures or installing colorful pots; and writing, painting, or hanging up pictures on the qiblah wall.

Most Ibadi scholars make a distinction in their rulings between the decoration and ornamentation of the qiblah wall and that of other walls [7]. The majority agree that the mosque must not be ornamented or decorated with sculptures or carvings [8], with pictures [13] or with colorful carpets, tapestries, or curtains [15]. Some scholars however, do tolerate the decoration of the mosque even with images, as long as those latter do not contain human faces [15], [13]. These scholars refer to an older opinion about this issue expressed by Abû Muhammad who stated:

"It is not acceptable to write Qur'anic verses or any exhortationson the qiblah wall, and it is prohibited to put pictures in the mosque. However, if these images do not show human faces, then there is no harm in performing the prayer in mosques that contain such pictures," as cited in [13].
This clear and unanimous interdiction by the Ibadi scholars to write on or paint the qiblah wall does not seem to have been observed in certain mosques in Oman, where mihrâbs made of stucco were decorated in various degrees of intricacy [7]. In interviews with several contemporary lbadi scholars, they confirmed the prohibition of ornamenting the qiblah wall, but they did not seem to have any explanation concerning those decorated prayer niches in Oman (Figure 2).

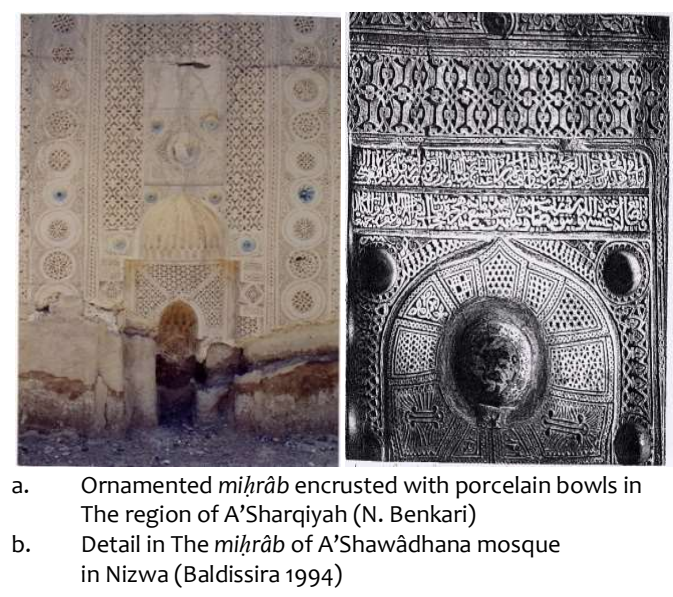

Figure 2: Ornamented miḷrâbs in Oman

12. The harîm of the mosque and conditions for construction of new prayer spaces

The mosque's harîm is defined in the books of Ibadi figh as being the distance around the mosque where it is not allowed to build another construction, plant trees or place garbage. This distance could be even wider for the location of public toilets [13]. Furthermore, Ahmad also prohibits the construction of ovens because the smoke could affect the neighboring houses. For this interdiction, he refers to the hadith: "One should not harm (oneself or others), nor reciprocate harm" (a sound hadith related by Ibn Mâjah and others) [13]. It must be explained that this hadith has become a fundamental principle in the Muslim community and in the management of its everyday life. Muslim scholars in all the schools of thought, refer to this hadith in their jurisprudence regarding the development and management of the city and neighborhood problem-solving [19], [20].

Related to the concept of the harîm is the issue of building other mosques in close proximity to an existing mosque. The majority of Ibadi scholars are against the construction of mosques too close to each other. This is to avoid a situation in which a new mosque jeopardizes the viability of the pre-existing one [10], [13], [15]. In the case where a new mosque is built close to a pre-existing one, it must be given the status of masjid dirâr (harmful mosque).

"Then there are those who establish a mosque to cause harm, and disbelief, and disunity among the believers, and as an outpost for those who fight God and His Messenger. They will swear: "Our intentions are nothing but good". But God bears witness that they are liars" (Quran, Sûrat al-Tawbahg:107). 
The Ibadi figh texts have defined what could be a harmful mosque: "Masjid dirâr is the sanctuary that is built close to or facing an existing older mosque which risks being abandoned and might therefore fall into decay due to the construction of the new mosque" [13].

However, some scholars consider that if the new mosque was built with a good intention and not with the aim to negatively affect the existing one, then it could be acceptable even if it threatens the viability of a pre-existing mosque. These scholars support their opinion with the principle, common in Islamic jurisprudence, that the good intention supersedes the risk of nuisance [13]. In order to avoid the community's dispersion due to the construction of many mosques that are close to each other, Ibadi scholars thought about defining a minimal distance from the existing mosque to be observed in case of new construction:

"A sufficient distance (from the initial mosque) should be observed so that when the call for the prayer is heard by a resident, he would have the time to make the ablutions, go to the mosque on foot and arrive on time for the communal prayer without having to choose between two mosques" [13].

Other scholars have used visibility (or rather, the lack of it) as a condition to allow a new mosque to be built near an existing one. None of the mosques should be seen from the other [13], [15]. If this condition is not observed, the new construction must be prohibited [13].

However, some scholars posited some exceptions to these rules. The first exception, which is accepted by most scholars, is the need to build a new mosque closer to some worshipers who are or have become disabled or too weak to reach the settlement's main mosque [13]. The second exception is given to people whose homes are too far from the settlement's mosque. The condition for this case is that the intention of the construction should not be to build a harmful mosque, but rather to accommodate the people who cannot attend daily communal prayers due to the great distance of their houses from the mosque [13].

Despite all these rules and conditions, in our visits to a certain number of Ibadi mosques in Oman, we observed a certain number of cases where mosques are too close to each other, such as in the city of Manah [7]. Abu Bakr Ahmad seemed to have referred to this particular case. We found reference to this particular statement of Abu Bakr Ahmad in most of the Ibadi fiqh books that came after Al-Musannaf. In this latter, Abu Bakr Ahmad states:

"Some cases of proximity between mosques exist and we have not heard about their condemnation by the believers. Yahyâ bin Qâsim bin Zakariyâ and his son built the mosque not far from the wâdi (valley, dry riverbed), then they built Al-Jannat mosque then Masjid Al-'Ain, and the three of them are on the same street" [13], [15].

From what preceded, it can be deduced that these scholars, having observed such exceptions firsthand, could have understood that the scholars before them had accepted these situations as exceptional. They use this conclusion as an argument for tolerating similar cases during their own time. This reflects an aspect of inter-influence mechanisms that might have taken place between the Ibadi jurisprudence and the practice of the community. Nevertheless, this remains a hypothesis that needs to be confirmed or rejected after further and more exhaustive research.

\section{CONCLUSION}

To conclude this analysis of the important texts of jurisprudence related to the construction and management of mosques in the Ibadi school of thought, we must stress the following aspects:

Even if the documents of the lbadi figh have specific authors, the content they reveal seems to have been accumulated through generations of scholarly work (ijtihâd). The texts they contain are compilations of legal opinions about the various topics addressed. This research has shown that the document explored in this paper has been a major source for the Ibadi jurisprudence that developed after its publication, and it remains so even today. It has also been made evident that the opinions expressed by Abu Bakr Ahmad in this book were developed based on the opinions and observations expressed by scholars who preceded him. This aspect is not specific to the Ibadi school of thought: the same phenomenon is observed in the other Islamic schools of thought [20].

On the other hand, we have seen that, although shared and accumulated by generations of scholars, these opinions were not homogeneous; some conflicts in the scholars' opinions were spotted (for example, the recommended height for the mosque's roof, the issue of multiple sanctuaries close to each other, sources of funding, and the question of ornamenting the mosque). This variation in legal opinions indicates that in spite of its inherent conservatism, lbadi jurisprudence gives its scholars the freedom and the tools to evolve and adapt the legislation to the transformations that the community goes through from time to time. Thus the community developed a balance between its religious convictions and rituals on one hand and its social and cultural conditions on the other, and these aspects have always influenced each other to reach this balance.

As mentioned above, this study was not exhaustive and its conclusions must be regarded as preliminary. It is necessary to develop the investigation further, to include all the references of the Ibadi school of thought. It would be useful to distinguish how each group has formulated its jurisprudence regarding the architecture of the mosque, and to be able to describe how the cultural and geographic characters have shaped this legal framework in each region to adapt it to its own local history, politics and social organization without negating the fundamental principles that still continue to unite the Ibadi communities throughout the Muslim world [21].

\section{REFERENCES}

[1] J. Schacht, Sur la diffusion des formes d'architecture religieuse musulmane à travers le 
Sahara. Travaux de l'Institut de Recherches Sahariennes, Tome XI., 1954.

[2] P. Cuperly, "La cité Ibadite?: urbanisme et vie sociale au Xle siècle (suite et fin)," AWAL, Cah. d'Etudes Berbères, vol. no. 4, p. 7-14., 1988.

[3] M. Mercier, La civilisation urbaine au M'Zab, Etude de Sociologie Africaine, Emile Pfis. Alger, 1922.

[4] A. Ravereau, Le M'Zab, une leçon d'architecture, Sindbad Ed. Paris, 1981.

[5] Donnadieu (C. et P) \& Didillon (H. et J. M.), Habiter le désert, les maisons mozabites? recherches sur un type d'architecture traditionnelle présaharienne. Bruxelles: Pierre Mardaga Editions, Architecture + Recherches, 1977.

[6] A. Haidar, Durar al-?ukkâm: shar?majallat ala?kâm. Beirut: Dâr al-Kutub al-'Ilmiyyah, 1991.

[7] B.-B. N, L'Architecture des mosquees Ibadites: M'zab, Djerba et Oman. Principes de conception et de construction. Tome II (Presses Un). Saarbrücken: Presses Académiques Francophones, 2014.

[8] A. Ath-Thamînî, Al-takmîl fi mâ akhalla bihi Kitâb al-Nîl(18c.). Tunis: Matba'at al-'Arab: Editedby M. I. S. A, 1944.

[9] P. Cuperly, "La cité Ibadite]?: urbanisme et vie sociale au Xle siècle," AWAL, Cah. d'Etudes Berbères, vol. no.3, p. 89-114., 1987.

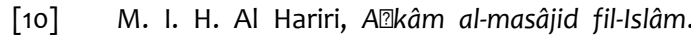
Riyadh: Dâr Al-Rifâ‘, 1990.
[11] A. B. A. 1993. A.-Q. wa usûl al-aradîn (12c. Ahmad, "Presented in modern Arabic by Mohammad Salah Nacer and Bekir Ben Mohammad Belhaj," 1993.

[12] M. Mercier, Etude sur le Waqf Ibadite et ses applications au M'Zab. Paris:Carbonel, 1927.

[13] A. B. A. 1983. A.-M. 1162 Ahmad, "presented in modern Arabic by A. Abdelmon'im. and A. Jâdallah," Minist. Herit. Cult. Muscat, Oman, vol. Vol. XIX, 1983.

[14] A. B. A. (12th. C. . presented by A. 'Amer and J. Ahmad, Al Muçannaf. 1983.

[15] A. Ath-Thamînî, Al-nîl wa shar?al-nîl(18c.),2nd ed. Algiers: Al-Matba'ahal-'Arabiyah li Dâr alFikr, 1967.

[16] A. I. O. (presentation) A-Thamini, Abdulaziz (18th. c.); Bakalli, A'Nîl wa Sharh A'Nîl. Algiers: Al Matba`a Al `Arabiya li dâr Al Fikr, ze Ed., 1967.

[17] R. n. . Hillenbrand, Masdjid, In Encyclo. Paris: Bri.

[18] G. Fehervari, "Mihrâb," Encycl. I'Islam, vol. VII, no. Paris: Nou, pp. 7-15, 1993.

[19] B. S. Hakim, Arabic-Islamic Cities: Building and Planning Principles. New York: EmergentCity Press., 2008.

[20] M. Ben-Hamouche, "Urban regulation in Islamic law through an Ottoman manuscript," J. Islam. Law Cult. 12(3), vol. 12 (3), pp. 284-307, 2010.

[21] J. Wilkinson, Changement et continuité en Oman, Editions C. Paris, 1980. 